\title{
Experimental infection of Atlantic halibut Hippoglossus hippoglossus with nodavirus: tissue distribution and immune response
}

\author{
S. Grove*, R. Johansen, B. H. Dannevig, L. J. Reitan, T. Ranheim \\ National Veterinary Institute, PO Box 8156 Dep., 0033 Oslo, Norway
}

\begin{abstract}
Atlantic halibut Hippoglossus hippoglossus, age $8 \mathrm{mo}$ and weighing $20 \mathrm{~g}$, were challenged by either intraperitoneal injection (i.p.) or by bath exposure using nodavirus isolated from Atlantic halibut. Fish were sampled at intervals over a $41 \mathrm{~d}$ period, starting on Day 5 post-challenge. Although no clinical disease or mortality was recorded, the data show that nodavirus did successfully propagate in i.p.-challenged fish. Using conventional end-point reverse transcription (RT)-PCR, nodavirus was detected in the kidney of all examined i.p.-challenged fish, and further in the head, heart, liver and posterior intestine of most of these individuals. Quantitative real-time RT-PCR revealed that the amount of virus in head samples from the i.p.-challenged group increased during the experiment. The presence of nodavirus in nervous tissue of i.p.-challenged fish was detected by immunohistochemistry from Day 13 post-challenge. In the retina, virus positive cells were found adjacent to the circumferential germinal zone at the ciliary margin towards the iris. In the brain, a few positive cells were detected in the tectum opticum. An ELISA was developed to detect anti-nodavirus activity in plasma. The method included an optimized coating procedure, which allowed the use of non-purified nodavirus as the coating antigen in a simple indirect ELISA. An anti-nodavirus antibody response was detected from Day 19 post-challenge in i.p.-challenged fish, while a response was not detected in the bath-challenged or control fish. This experiment demonstrates a subclinical nodavirus infection in Atlantic halibut at a post-juvenile stage induced by i.p. injection of virus.
\end{abstract}

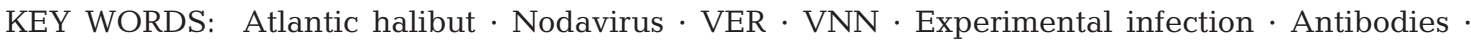
RT-PCR $\cdot$ ELISA $\cdot$ Immunohistochemistry

\section{INTRODUCTION}

Piscine nodaviruses are the causative agents of viral encephalopathy and retinopathy (VER), also known as viral nervous necrosis (VNN). The disease affects at least 20 marine fish species worldwide (Curtis et al. 2001, Starkey et al. 2001, Munday et al. 2002). Nodaviruses are icosahedral, with a diameter of 25 to $30 \mathrm{~nm}$, and consist of a single coat protein and a bi-segmented genome, RNA1 and RNA2 (Mori et al. 1992, Iwamoto et al. 1999). VER is considered to be one of the most serious viral diseases affecting larvae and juvenile marine fishes (Munday \& Nakai 1997), and the disease usually results in high mortality rates (Fukuda et al.
1996). Affected fishes exhibit a range of neurological signs. Necrotic and highly vacuolated areas in central nervous tissue and retina are typical histopathological lesions and electron microscopy reveals aggregates of non-enveloped virus particles in the cytoplasm of nerve cells (Munday et al. 1997).

Outbreaks of VER were first recognized in farmed Atlantic halibut Hippoglossus hippoglossus larvae and juveniles in Norway in 1995 (Grotmol et al. 1995, 1997). Dannevig et al. (2000) isolated the causal virus from farmed Atlantic halibut suffering from VER using the SSN-1 cell line, a cell line proven to be susceptible to nodaviruses from different fish species (Frerichs et al. 1996, Iwamoto et al. 1999), and demonstrated that 
challenge of Atlantic halibut larvae with cell culturepropagated virus resulted in high mortality and the development of VER (Dannevig et al. 2000).

Cultured Atlantic halibut are believed to be susceptible to nodavirus infection only in the early juvenile stages before their immune system is fully developed (Grotmol et al. 1997). Bath challenge of Atlantic halibut larvae with nodavirus has produced high mortality and clinical signs of VER (Grotmol et al. 1999, Dannevig et al. 2000). In a recent study, Johansen et al. (2002) observed a subclinical, persistent infection in Atlantic halibut at the juvenile stage ( $5 \mathrm{~g}, 4$ to $8 \mathrm{mo}$ ). Subclinically infected spawners seem to be one of the main sources of nodavirus infection in several marine species (Mushiake et al. 1994, Breuil \& Romestand 1999, Watanabe et al. 2000), but so far nodavirus has not been detected in Atlantic halibut spawners (Grotmol et al. 1997, Grotmol \& Totland 2000). Selection of nodavirus-free spawners by RT-PCR and ELISA has been of great importance for reduction of VER in juvenile sea bass and striped jack (Watanabe et al. 2000).

Further studies are needed to reveal how and when the spawners are infected by nodavirus and where the virus resides in the infected fish. Vaccination of spawners seems to be one possibility for preventing spread of nodavirus to their offspring. Therefore, more information on the immune response to nodavirus, the pathogenesis of nodavirus infection, and experimental infection-models is needed. In the present study, we investigated whether immune competent Atlantic halibut (10 to $40 \mathrm{~g}$ ) were susceptible to nodavirus infection when challenged with virus isolated from naturally infected Atlantic halibut.

\section{MATERIALS AND METHODS}

Cell cultures. The SSN-1 cell line (Frerichs et al. 1996) obtained from The European Collection of Animal Cell Cultures (ECACC; Salisbury, UK), was grown in Leibovitżs L15-medium supplemented with 5\% fetal bovine serum (FBS), L-glutamine $\left(4 \mathrm{mmol} \mathrm{l}^{-1}\right)$, and gentamicin $\left(50 \mu \mathrm{g} \mathrm{ml}^{-1}\right)$ (Bio Whittaker) using Falcon Primaria cell culture flasks (Becton Dickinson Labware). The cells were grown at $25^{\circ} \mathrm{C}$.

Virus. Nodavirus (AHNNV 692/9/98) was isolated from Atlantic halibut Hippoglossus hippoglossus juveniles during an outbreak of VER in a Norwegian fish farm (Dannevig et al. 2000) using the SSN-1 cell line. For production of virus to be used in the challenge experiments and as antigen in the ELISA (see below), SSN-1 cells were inoculated with a third passage of virus.

Virus suspension: When pronounced cytopathic effects (CPE) on inoculated cultures were observed (on
Day 6 post-infection), the cell cultures were frozen and thawed once. Cell culture fluids were harvested and clarified by centrifugation at $1500 \times g$ for $15 \mathrm{~min}$. Supernatants were collected and stored at $-80^{\circ} \mathrm{C}$. Virus titration was conducted on monolayers of SSN-1 cells grown in 96-well microtitre plates using 6 wells per dilution (10-fold serial dilution). After $10 \mathrm{~d}$ incubation, the cultures were examined for infection by nodavirus by an indirect immunofluorescence technique (IFAT), essentially as described by Dannevig et al. (2000). An antiserum against AHNNV was used as the primary antibody. This antiserum ( $\mathrm{K}$ 672) was obtained by immunizing a rabbit with $\mathrm{CsCl}$ gradient purified AHNNV (T. Ranheim unpubl. data). Fluorescein isothiocyanate (FITC)-labeled goat anti-rabbit IgG (Southern Biotechnology Associates) was used as secondary antibody. To facilitate observation in the fluorescence microscope, nuclei were stained by addition of $10 \mu \mathrm{g} \mathrm{ml}^{-1}$ propidium iodide (Sigma). TCID $50 \mathrm{ml}^{-1}$ (tissue-culture infectious dose infecting $50 \%$ of inoculated cultures) was calculated according to the method of Kärber (1931)

Cell lysate: When moderate CPE were observed (i.e. the cells were still attached to the surface of the culture flask), the culture medium was removed and the remaining cells were rinsed once with phosphatebuffered saline (PBS) (pH 7.2), scraped off the culture flasks and suspended in a small volume of PBS. The cells were frozen and thawed 3 times to ensure a complete release of viral antigens. The lysate was centrifuged, and the supernatant was stored in small aliquots at $-80^{\circ} \mathrm{C}$.

The protein concentration was quantified by the method of Lowry (Lowry et al. 1951), using bovine serum albumin (BSA) as the protein standard.

Challenge. We obtained 200 Atlantic halibut of $17.2 \mathrm{~g}$ average weight (range 10 to $40 \mathrm{~g}$ ), from a commercial fish farm, and kept them at VESO Vikan AkvaVet (Namsos, Norway) during the experiment. The fish were 8 mo of age. The fish were placed in tanks containing seawater $(26.3$ to $33.8 \% \mathrm{~S})$ at $12^{\circ} \mathrm{C}$, and were acclimated for $17 \mathrm{~d}$. They were fed ad libitum twice daily with pelleted feed (Dana Feeds, Dana-Ex $3 \mathrm{~mm}$ ). Before the onset of the experiment, 5 fish were examined for nodavirus by RT-PCR (as described below), and all were found to be negative for the virus. Blood samples from these fish were included in the examination of the humoral immune response by ELISA, as described below. Three days prior to the challenge, the fish were divided into 5 tanks (numbered 1 to 5). On Day 0 of the experiment, 30 fish (Tank 1) were left unchallenged, and served as controls. The fish of Tanks 2 and 3, with 30 and 50 fish respectively, were bath-challenged for $2 \mathrm{~h}$ by adding the virus directly into 501 seawater (final dose $10^{5}$ 
TCID $_{50} \mathrm{ml}^{-1}$ ). Tank 2 was used for mortality surveillance, while Tank 3 was used for sampling. The fish of Tanks 4 and 5, with 40 and 50 fish respectively, were challenged by intraperitoneal (i.p.) injection. The fish were anaesthetized in $0.05 \%$ o benzocain and each fish received $0.1 \mathrm{ml}$ of a suspension of virus with $10^{7}$ TCID $_{50} \mathrm{ml}^{-1}$. Tank 4 was used for mortality surveillance, while Tank 5 was used for sampling. Abnormal behavior and mortality were recorded daily during the experiment.

Sampling. On Days 5, 7, 13, 19 and 41, post challenge, 8 i.p.-challenged fish were sacrificed; on Days 7 , $13,19,32$ and 41, 8 bath-challenged fish were sacrificed; on Days 5, 7, 13, 19, 32 and 41, 3 control fish were sacrificed. Since we expected an earlier mortality in the i.p.-challenged group than the bath-challenged group (Peducasse et al. 1999), the fish in the i.p.-challenged group were collected more frequently at the beginning of the experiment.

The fish were anaesthetized in $0.05 \%$ benzocain, and blood was drawn from the caudal vein using heparin-containing Venoject sampling tubes (Teromo Europe). Plasma was isolated by standard centrifugation, and stored at $-20^{\circ} \mathrm{C}$ after addition of $\mathrm{NaN}_{3}$ (15 mM). From each sacrificed fish, brain and eyes or the whole head were sampled along with kidney, thymus, spleen, heart, liver, anterior and posterior intestine, pancreas, muscle, skin and gills (Table 1). Tissue samples for total RNA isolation were instantly frozen in liquid nitrogen, and stored at $-70^{\circ} \mathrm{C}$. Tissue samples for histopathology and immunohistochemistry (IHC) were fixed in neutral phosphate-buffered $10 \%$ formalin and embedded in paraffin wax. The brains and retinas intended for microscopy investigations were fixed whole. This was done to enable examination of all parts of the organs and to ensure correct orientation.

Total RNA isolation and conventional RT-PCR. The frozen specimens were homogenized in PBS with a laboratory blender (Stomacher 80) before analysis. Isolation of total RNA from the homogenized tissue was performed using the RNeasy kit (Qiagen). The reverse transcription (RT) and DNA amplification were carried out in 1 tube using the GeneAmp EZ rTth RNA PCR kit (Perkin Elmer) in the presence of 0.5 $\mu \mathrm{g}$ total RNA, $0.5 \mu \mathrm{M}$ of the forward primer 5'-CTG-AAG-ATA-CAT-TCGCTC-CAA-3' and $0.5 \mu \mathrm{M}$ of the reverse primer 5'-TAT-CCC-ATA-GCC-CCCAGT-G-3'. The RT step at $60^{\circ} \mathrm{C}$ for 30 min. was followed by an initial step of $94^{\circ} \mathrm{C}$ for $2 \mathrm{~min}$, followed by 30 cycles of a 2-temperature polymerase chain reaction (PCR) $\left(94^{\circ} \mathrm{C}\right.$ for $45 \mathrm{~s}, 55^{\circ} \mathrm{C}$ for $\left.45 \mathrm{~s}\right)$, and ended with $60^{\circ} \mathrm{C}$ for $7 \mathrm{~min}$. A distinct band of $264 \mathrm{bp}$ was detected on a $2 \%$ agarose gel.

Quantitative real-time RT-PCR. A LightCycler-RNA master hybridazation probe kit (Roche Diagnostics) was used in combination with a LightCycler instrument (Roche Diagnostics) for the amplification and detection of the RNA target. The specific fragment was transcribed and amplified with the primers described in the preceding subsection in combination with a TaqMan sequencespecific probe labeled 5'-FAM TTC-AAA-TCA-ATACTT-CTT-GGC-TCT-A 3'-TAMRA (DNA Technology $\mathrm{A} / \mathrm{S})$. The RT-PCR reactions were performed in narrow glass capillaries in a reaction volume of $25 \mu \mathrm{l}$. The reaction mix contained final concentrations of $1 \times$ LightCycler RNA master hybridization mix, $0.2 \mu \mathrm{g}$ total RNA, $0.5 \mu \mathrm{M}$ of each primer, $0.2 \mu \mathrm{M}$ probe, and $2.5 \mathrm{mM} \mathrm{Mn}(\mathrm{OAc})_{2}$. The RT step at $61^{\circ} \mathrm{C}$ for $20 \mathrm{~min}$ was followed by a denaturation step at $95^{\circ} \mathrm{C}$ for $2 \mathrm{~min}$, followed by 45 cycles of a 3-temperature $\mathrm{PCR}\left(95^{\circ} \mathrm{C}\right.$ for $10 \mathrm{~s}, 57^{\circ} \mathrm{C}$ for $20 \mathrm{~s}$, and $72^{\circ} \mathrm{C}$ for $13 \mathrm{~s}$ ) ending at $40^{\circ} \mathrm{C}$ for $30 \mathrm{~s}$.

Histology and immunohistochemistry (IHC). Tissue sections $(1.5$ to $2 \mu \mathrm{m})$ were stained with haematoxylineosin (HE) or immunostained.

Immunohistochemical detection of nodavirus was performed with a streptavidin-biotin-alkaline-phosphatase complex technique essentially according to Dannevig et al (2000). Briefly, after deparaffination, nonspecific antibody binding sites were blocked with $5 \%$ BSA in Tris-buffered saline (TBS, pH 7.4) for $20 \mathrm{~min}$. The sections were incubated for $30 \mathrm{~min}$ with polyclonal rabbit AHNNV-antiserum (K672) diluted 1:500 in TBS with $2.5 \%$ BSA (TBS/BSA). Sections were then incubated for 30 min with biotinylated goat antirabbit IgG (Dako), diluted 1:500 in TBS/BSA, and thereafter incubated for 30 min with a streptavidin-

Table 1. Hippoglossus hippoglossus. Allocation of samples from each sampling to histology, immunohistochemistry (IHC), RT-PCR and ELISA analyses. When sampled, 3 control fish and 8 fish from each of the challenged groups were sacrificed. At each sampling, brain and 1 eye from 1 control and 2 challenged fish were sampled for an intended transmission electron microscopy examination which was not performed. The other eye of these fish was sampled for IHC examination. Histology: kidney, anterior and posterior intestine, heart, liver, gills, pancreas, thymus, muscle, skin and spleen were also examined. In fish with positive IHC staining in brain and/or eye, additional IHC analyses of kidney, anterior and posterior intestine, heart, liver, gills and thymus were performed

\begin{tabular}{|c|c|c|c|c|c|}
\hline \multirow{2}{*}{ Group } & \multicolumn{2}{|c|}{ Histology and IHC } & \multicolumn{2}{|c|}{ RT-PCR } & \multirow{2}{*}{$\begin{array}{l}\text { ELISA } \\
\text { Blood }\end{array}$} \\
\hline & Brain & Eye & Whole head & Tissues $^{\mathrm{a}}$ & \\
\hline Control $(\mathrm{n}=3)$ & 1 & 2 & 1 & 3 & 3 \\
\hline Challenged $(n=8)^{b}$ & 3 & 5 & 3 & 3 & 8 \\
\hline \multicolumn{6}{|c|}{ aKidney, posterior intestine, heart, liver and gills } \\
\hline
\end{tabular}


alkaline-phosphate complex (Amersham International) diluted 1:500 in TBS/BSA. Finally, the sections were incubated with Fast Red salt (1 $\mathrm{mg} \mathrm{ml}^{-1}$, Sigma ) for $20 \mathrm{~min}$. The preparations were washed twice in TBS between each incubation step. All incubations were carried out in a humidity chamber at room temperature. The sections were counter-stained with haematoxylin and examined by light microscopy. Tissue sections from halibut known to be infected with nodavirus were incubated with the anti-AHNNV antiserum as a positive control and with pre-immune rabbit serum as a negative control in each test.

Brain and 1 eye from 1 control fish and 2 fish from each challenge group at each sampling were fixated in $3 \%$ glutaraldehyde in a $0.1 \mathrm{M}$ cacodylate buffer, $\mathrm{pH}$ 7.4. These samples were not examined further in electron microscopy because of the sparse pathological findings and low number of immunopositive cells found under light microscopy.

ELISA. Optimization of the assay and quantification of the plasma antibodies were carried out as follows.

Optimization of ELISA: An ELISA for detection of anti-nodavirus antibodies in Atlantic halibut plasma was developed, in which the specific binding of nodavirus antigen in the coating process was optimized. Coating buffers with varying concentrations of salt were produced by adding either $\mathrm{NaCl}$ or saturated $\left(\mathrm{NH}_{4}\right)_{2} \mathrm{SO}_{4}$ (at $4^{\circ} \mathrm{C}$ ) to a standard carbonate coating buffer (15 mM Na${ }_{2} \mathrm{CO}_{3}, 35 \mathrm{mM} \mathrm{NaHCO}{ }_{3}, \mathrm{pH}$ 9.6). The tested coating buffers contained $\mathrm{NaCl}(0$ to $2.5 \mathrm{M})$ or were saturated with $\left(\mathrm{NH}_{4}\right)_{2} \mathrm{SO}_{4}$ in the range of 0 to $40 \%$ (i.e. 0 to $1.83 \mathrm{M}$ ). The coating solutions contained coating buffers and cell lysate from nodavirus infected or non-infected SSN-1 cell cultures (total protein concentration $7.6 \mu \mathrm{g} \mathrm{ml} \mathrm{g}^{-1}$ ). Microtitre plates (Maxisorp F96, Nunc) were coated overnight. The following incubations were carried out at room temperature for $1 \mathrm{~h}$ unless specified otherwise, and the various steps were separated by 3 washes in PBS with $0.1 \%$ Tween 20 (PBST). After a blocking incubation with $5 \%$ skimmed milk powder in PBST, the plates were incubated with Atlantic halibut plasma in PBS with $0.5 \%$ Tween 20 . The plates were further incubated with polyclonal rabbit anti-Atlantic halibut IgM antiserum (K628, S. Grove et al. unpubl.) (1:500 in PBST) followed by incubation with horseradish peroxidase-conjugated donkey anti-rabbit Ig antiserum (NA934, Amersham Life Science) (1:1000 in PBST). Finally, the plates were incubated for $20 \mathrm{~min}$ with $0.067 \%$ (w/v) o-phenyldiamine (Sigma, P8287), $0.0126 \% \mathrm{H}_{2} \mathrm{O}_{2}$ in $0.05 \mathrm{M}$ phosphate-citrate buffer, $\mathrm{pH}$ 5.0. This reaction was stopped by addition of $2 \mathrm{M}$ $\mathrm{H}_{2} \mathrm{SO}_{4}$ and the optical density at $492 \mathrm{~nm}\left(\mathrm{OD}_{492}\right)$ was measured with a Multiskan EX 355 spectrophotometer (Labsystems).
Quantification of anti-nodavirus antibodies in plasma: ELISA was performed as above using a coating solution containing $0.8 \mathrm{M} \mathrm{NaCl}$. Plasma samples from all sampled individuals of Atlantic halibut were analyzed in duplicates against cell lysate from nodavirus infected (test) and non-infected (control) cell cultures. The resulting OD values were calculated from the formula: mean of $\mathrm{OD}_{\text {test }}-$ mean of $\mathrm{OD}_{\text {control }}$.

Detection of virus neutralizing activity. Selected plasma samples from Day 41 post-challenge were analyzed for their neutralizing activity. The 6 strongest sero-positive from the i.p.-challenged group and the 2 most sero-negative from the control group, as determined by ELISA, were selected. Plasma was heat inactivated at $43^{\circ} \mathrm{C}$ for $45 \mathrm{~min}$ and 2 -fold serial dilutions of the plasma in L-15 without FBS were mixed with an equal volume of virus suspension containing $4 \times 10^{2}$ TCID $_{50} \mathrm{ml}^{-1}$. Following incubation at $20^{\circ} \mathrm{C}$ for $1.5 \mathrm{~h}$, $50 \mu \mathrm{l}$ of each plasma-virus mixture was added to SSN-1 cells grown in 96-well plates (3 parallel wells per plasma dilution for each virus dose). After $1 \mathrm{wk}$ incubation at $20^{\circ} \mathrm{C}$, the cells were fixed in $80 \%$ acetone and stained for AHNNV by IFAT as described above. Neutralizing activity was expressed as the reciprocal value of the plasma dilution that inhibited virus infection in $50 \%$ of the inoculated cultures.

Statistical analyses. The ELISA results are presented as mean values with $95 \%$ confidence intervals; the differences between control and treatment groups were tested using a Student's $t$-test and $\mathrm{p}<0.05$ was considered statistically significant.

\section{RESULTS}

\section{Clinical signs}

No lack of appetite, abnormal behavior or mortality was recorded in any of the experimental groups of Hippoglossus hippoglossus during the experiment. The fish gained weight during the experimental period, from a mean 17.2 to $40.5 \mathrm{~g}$.

\section{Histopathology}

Tissue from brain, eye, heart, gills, kidney, liver, intestine, spleen, thymus, pancreas, muscle and skin was examined by light microscopy. No typical pathological manifestation of nodavirus infection was found, except for some vacuolization of the inner nuclear cell layer of the retina in a few fish in the i.p.-challenged group. Epicarditis was seen in the majority of examined fish regardless of the treatment throughout the experiment. An additional study of untreated fish at the farm 
that provided the fish for this study showed that $90 \%$ of the fish of this size had epicarditis (Johansen \& Poppe 2002). No other pathological changes were seen in control and bath-challenged fish or in the other examined organs of the i.p.-challenged fish.

\section{Immunohistochemistry}

Specific immunolabeling against nodavirus was performed. Immunolabeling was not detected in any control or bath-challenged fish. In the i.p.-challenged fish, heart, gills, kidney, thymus, pancreas, liver, anterior and posterior intestine was consistently nodavirus negative at all samplings (data not shown). At Day 7 postchallenge, no reactivity was observed either in the retina or in the brain of i.p.-challenged fish, but at Days 13, 19 and 41 immunolabeling was detected in the retina (8 of 13 fish) and in the brain (3 of 9 fish) (Table 2). In the retina, single positive cells or small foci of positive cells were found in the inner nuclear cell layer and ganglion layer adjacent to the circumferential germinal zone at the ciliary margin towards the

Table 2. Hippoglossus hippoglossus. Immunohistochemical detection of nodavirus in retina and brain of i.p.-challenged fish. Number of fish showing positive reaction/total number of fish examined is shown

\begin{tabular}{|ccc|}
\hline $\begin{array}{c}\text { Days post } \\
\text { challenge }\end{array}$ & Retina & Brain \\
\hline 7 & $0 / 5$ & $0 / 2$ \\
13 & $2 / 5$ & $1 / 3$ \\
19 & $2 / 4$ & $1 / 3$ \\
41 & $4 / 4$ & $1 / 3$ \\
\hline
\end{tabular}

iris (Fig. 1). In the brain, a few immunopositive cells were found in the tectum opticum (Fig. 2).

\section{Virus detection by RT-PCR}

We employed a sensitive assay that allows precise and specific detection of the fish nodavirus from Atlantic halibut. Conventional RT-PCR was performed with total RNA isolated from fish tissue as template. Primers corresponding to the nucleotide sequence from the RNA2 sequence of Atlantic halibut nodavirus characterized by Grotmol et al. (2000), were used and a $264 \mathrm{bp}$ PCR fragment was amplified. We examined several different tissues from each fish by conventional RT-PCR (Table 1). A distinct band of approximately 264 bp was only evident in samples from the i.p.-challenged group (Table 3). Positive signals were detected in the kidney and posterior intestine from Day 5 post challenge and in head and liver samples from Day 13 post challenge. In heart samples, positive findings were irregular. Gills were negative at all samplings. We also examined the head samples from all 3 groups by real-time quantitative RT-PCR. This method confirmed to a high degree the data from the conventional RT-PCR, showing the same head samples of i.p.-challenged fish to be nodavirus-positive (Fig. 3). Only, a single bath-challenged fish sampled on Day 32 was also shown to be very weakly positive (data not shown) as was a single i.p.-challenged fish sampled on Day 5 (Fig. 3). The quantification further showed increasing amounts of viral nucleic acids in heads sampled late in the experiment (Fig. 3). Control fish and the remainder of the bath-challenged fish consistently yielded negative results using this technique.
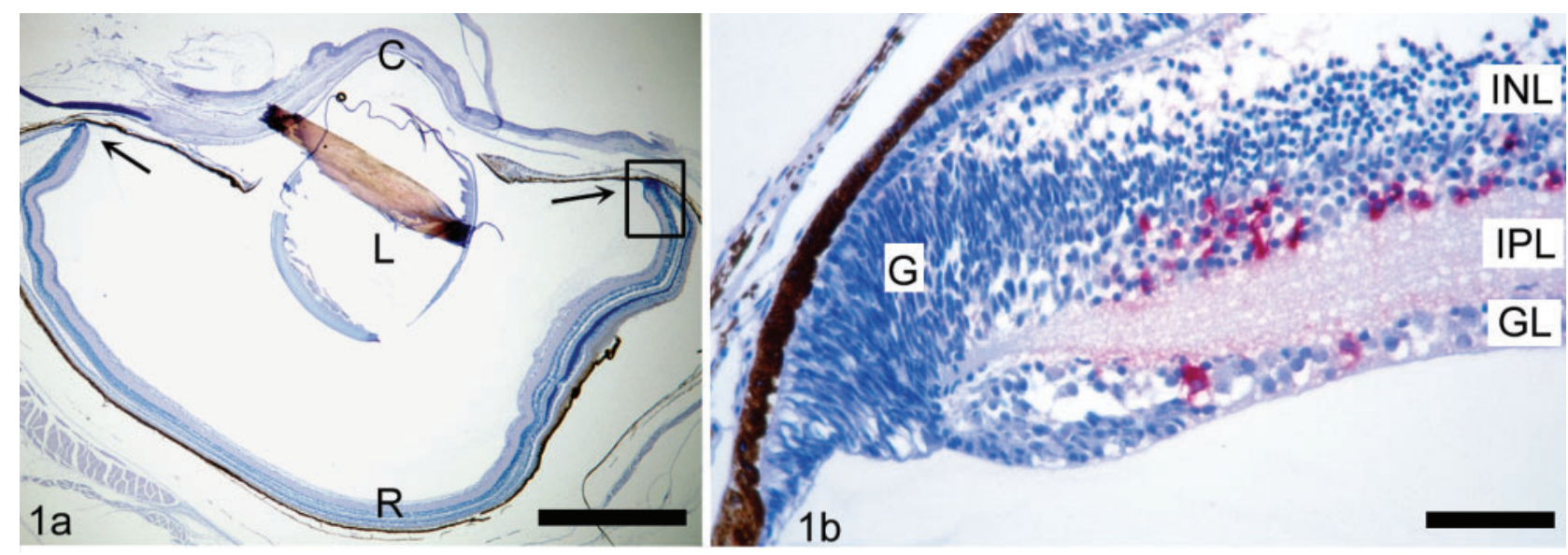

Fig. 1. Hippoglossus hippoglossus. Immunohistochemical staining of retina from fish sampled on Day 13 after i.p. challenge with nodavirus. (a) Transverse section of entire retina (R) showing circumferential germinal zone (arrows), remains of lens ( $\mathrm{L}$, disrupted during sectioning) and cornea $(\mathrm{C})$. Scale bar $=1 \mathrm{~mm}$. (b) Higher magnification of inset in (a). Immunopositive cells (red) are located in inner nuclear cell layer (INL) and ganglion layer (GL) close to germinal zoone (G). IPL = inner plexiform layer. 

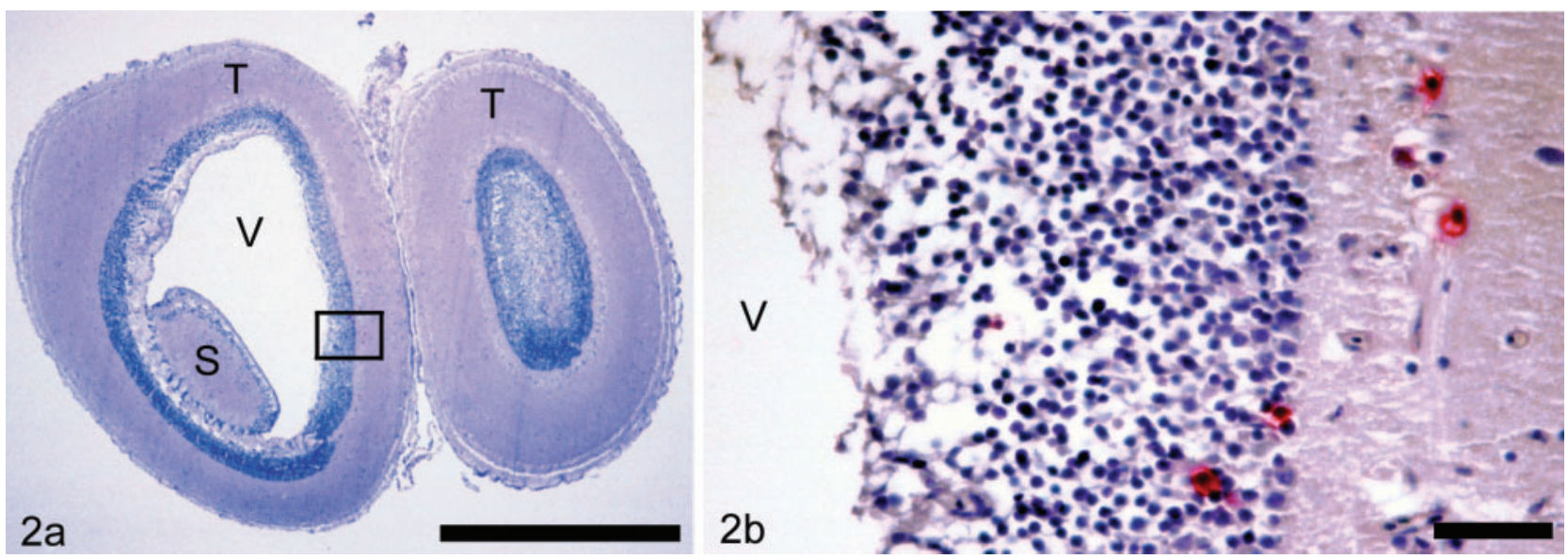

Fig. 2. Hippoglossus hippoglossus. Immunohistochemical staining of brain from fish sampled on Day 13 after i.p. challenge with nodavirus. (a) Section through tectum opticum (T) of brain. In left tectum opticum, ventricle (V) and torus semicircularis (S) are shown; section of right tectum opticum is located more dorsally, outside the ventricle. Scale bar $=1 \mathrm{~mm}$. (b) Higher magnifica-

tion of inset in (a). Few immunopositive cells (red) were found in tectum opticum. V = ventricle lumen. Scale bar $=50 \mu \mathrm{m}$

\section{Optimization of ELISA}

The binding efficiency of nodavirus antigen was shown to depend on the salt content of the coating buffer (Fig. 4). For both $\mathrm{NaCl}$ and $\left(\mathrm{NH}_{4}\right)_{2} \mathrm{SO}_{4}$, optimal binding was seen within a limited range of salinities. For $\mathrm{NaCl}$, the optimal range was somewhat broader than for $\left(\mathrm{NH}_{4}\right)_{2} \mathrm{SO}_{4}$. Addition of $\left(\mathrm{NH}_{4}\right)_{2} \mathrm{SO}_{4}$ affected the $\mathrm{pH}$ of the coating buffer (e.g. from $\mathrm{pH} 9.6$ to $\mathrm{pH} 7.8$ at $15 \%$ saturation, i.e. $0.62 \mathrm{M}$ ). However, a $15 \%$ $\left(\mathrm{NH}_{4}\right)_{2} \mathrm{SO}_{4}$ coating buffer re-equilibrated to $\mathrm{pH} 9.6$ showed a similar performance as the buffer at $\mathrm{pH} 7.8$ (data not shown). Further, without additional salt added, 0.1 M phosphate buffer at pH 7.8 showed binding that was similar to the standard $0.05 \mathrm{M}$ carbonate buffer ( $\mathrm{pH}$ 9.6) (data not shown).

\section{Humoral immune response}

An increase in the anti-nodavirus antibody activity was observed in the i.p.-challenged fish (Fig. 5). The difference between the i.p.-challenged and control fish was significant $(p<0.05)$ from Day 19 post challenge. Neither bath-challenged nor control fish showed an increase in antibody activity.

Preliminary analyses using pooled plasma samples (Day 41 post challenge) from control fish, from bathchallenged fish and from i.p.-challenged fish respectively, revealed that the control and the bath-challenged groups only had very low neutralizing activity and that the activity of the i.p.-challenged group was limited (data not shown).

Individual plasmas were then selected as described above. Neutralizing activity against nodavirus was observed in plasma of i.p.-challenged fish at a final plasma dilution of approximately 1:160 for the lowest virus dose (Table 4). The samples from the challenged fish showed OD values in the ELISA in the range of 0.6 to 1.15 , while values of control fish were lower than 0.17 . The Atlantic halibut plasma showed toxic effects at a dilution of 1:20 or lower, making it difficult to estimate the exact neutralizing activity of plasma from control fish.
Table 3. Hippoglossus hippoglossus. Detection of nodavirus by conventional RTPCR in i.p.-challenged fish $(n=3)$. Number of PCR-positive fish at each sampling is shown

\begin{tabular}{|ccccccc|}
\hline $\begin{array}{c}\text { Days post- } \\
\text { challenge }\end{array}$ & $\begin{array}{c}\text { Head } \\
\text { (brain/eyes) }\end{array}$ & Gills & Heart & Kidney & Liver & $\begin{array}{c}\text { Posterior } \\
\text { intestine }\end{array}$ \\
\hline 5 & 0 & 0 & 1 & 3 & 0 & 2 \\
7 & 0 & 0 & 0 & 3 & 0 & 2 \\
13 & 3 & 0 & 1 & 3 & 2 & 3 \\
19 & 2 & 0 & 3 & 3 & 3 & 3 \\
41 & 3 & 0 & 0 & 3 & 3 & 3 \\
\hline
\end{tabular}

\section{DISCUSSION}

In the present study Atlantic halibut, Hippoglossus hippoglossus, 10 to $40 \mathrm{~g}$, were successfully infected with nodavirus by i.p.-challenge, and IHC and RT-PCR were used to detect the presence of nodavirus in several organs from these fish. Furthermore, a specific antibody response to nodavirus was also detected. However, clinical signs of disease typical 


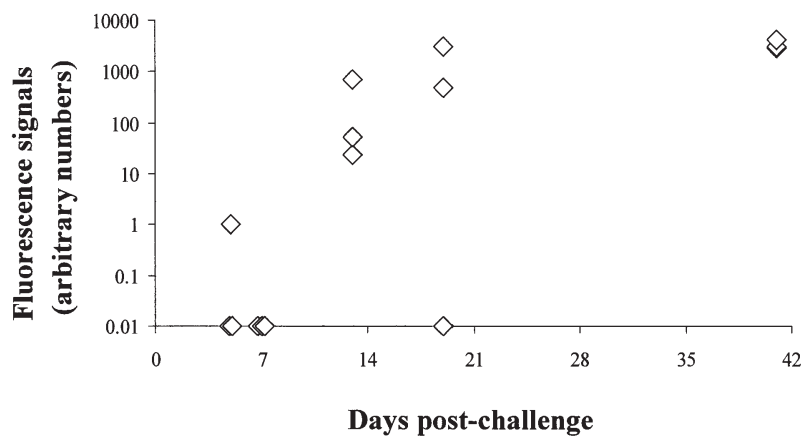

Fig. 3. Hippoglossus hippoglossus. Detection of nodavirus in head samples by quantitative real-time RT-PCR. Only results from i.p.-challenged group are shown. Each data point represents result for 1 fish. Values were obtained from the amplification curves and are given as arbitrary numbers during the log-linear phase of PCR. Data points on the baseline (i.e. at $y=$ 0.01 ) were determined as zero, but were assigned a value of 0.01 to fit the logarithmic presentation. Arbitrary values above 1 were considered positive

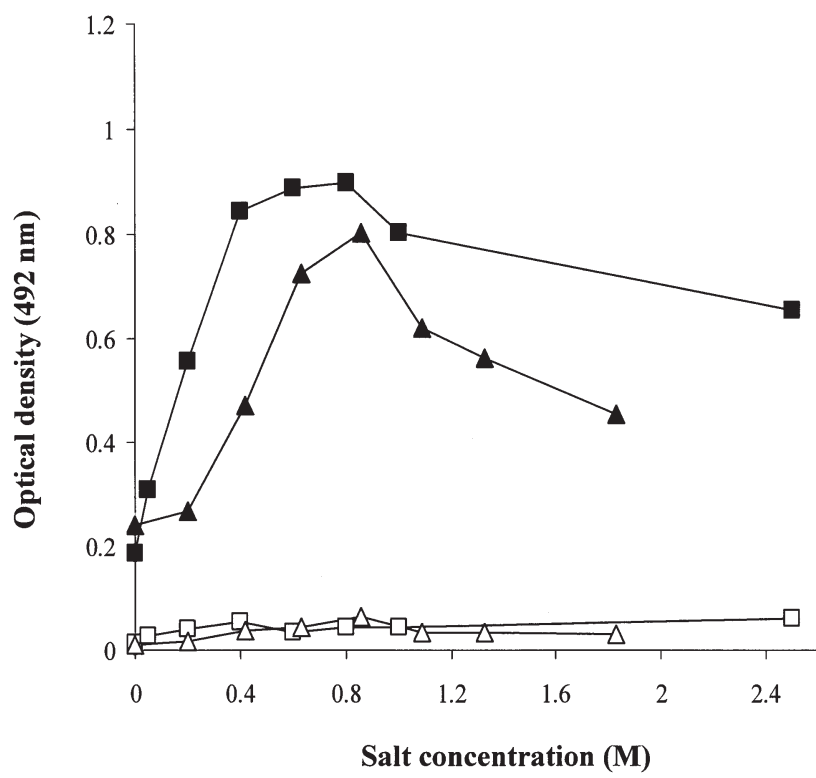

Fig. 4. Hippoglossus hippoglossus. Effect of coating solution salinity on nodavirus antigen-binding efficiency in ELISA. Coating solutions with different concentrations of $\left(\mathrm{NH}_{4}\right)_{2} \mathrm{SO}_{4}$ or $\mathrm{NaCl}$ were analyzed by ELISA using anti-nodavirus positive and negative Hippoglossus hippoglossus plasma samples as primary antibodies. Coating solutions with $(\boldsymbol{\Lambda}, \triangle)$ $\left(\mathrm{NH}_{4}\right)_{2} \mathrm{SO}_{4}$ and with $(\boldsymbol{\square}, \square) \mathrm{NaCl}$. Black symbols: antinodavirus positive Atlantic halibut plasma $(n=4)$. White symbols: anti-nodavirus negative Atlantic halibut plasma $(\mathrm{n}=4)$

for VER were not observed in the i.p-challenged group, suggesting that a subclinical infection had occurred

Bath-challenge should be the preferred experimental model for nodavirus infection, as horizontal transmission has been demonstrated for several species

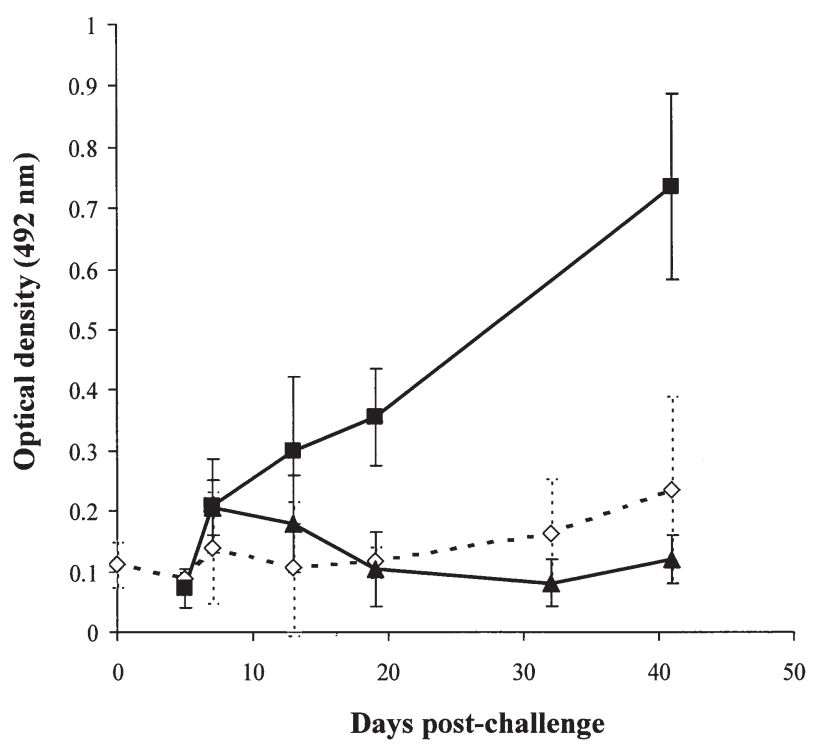

Fig. 5. Hippoglossus hippoglossus. Average anti-nodavirus antibody activity in plasma from challenged and non-challenged Atlantic halibut analyzed by ELISA. Individual plasma samples, diluted 1:100, were tested in duplicates against cell lysate from SSN-1 cells infected (test) or not infected (control) with nodavirus. Results for individual plasma samples are calculated as (mean of $\mathrm{OD}_{\text {test }}-$ mean of $\mathrm{OD}_{\text {control }}$ ). (苗) i.p.-challenged group $(\mathrm{n}=8) ;(\boldsymbol{\Lambda})$ bath-challenged group $(\mathrm{n}=8)(\diamond)$ untreated control group ( $\mathrm{n}=3$ except Day 0 , when $\mathrm{n}=5)$. Bars represent $95 \%$ confidence intervals

(Breuil et al. 2000). Infection by bath-challenge of larvae and juveniles has resulted in mortalities varying from low levels up to $100 \%$ (Arimoto et al. 1993, Peducasse et al. 1999, Huang et al. 2001, Húsgarð et al. 2001). In all these studies, the existence of infection was demonstrated by characteristic histopathology and/or detection of nodavirus in retina and brain by IHC and/or RT-PCR. Bath-challenge of Atlantic halibut larvae with nodavirus has resulted in clinical signs of VER and 100\% mortality (Dannevig et al. 2000, Grotmol et al. 1999). In the present study, only a single fish of the bath-challenged group was revealed as weakly positive by quantitative real-time RT-PCR on Day 32 post challenge. Several factors such as virus strain, virus dose, water temperature, fish age and duration of experiment might explain the sparse evidence for an infection in the bath-challenged group. To our knowledge, successful infection by bath challenge of larger fish has not been reported; this is in accordance with the suggestion that age is one of the most important factors for the development of overt nodavirus infection. A specific antibody response was not detected in the bath-challenged group indicating that specific humoral immune mechanisms were not triggered.

In the i.p.-challenged fish, nodavirus was detected in the kidney and other internal organs at an earlier time 
Table 4. Hippoglossus hippoglossus. Nodavirus neutralizing activity and the corresponding anti-nodavirus antibody activity (ELISA optical density[OD]-values) of individual Atlantic halibut plasma. Plasma from individual fish sampled on Day 41 post-challenge was examined against a nodavirus suspension containing $4 \times 10^{2} \mathrm{TCID}_{50}$ (tissue-culture infectious dose infecting $50 \%$ inoculated cultures) $\mathrm{ml}^{-1}$

\begin{tabular}{|lcc|}
\hline Treatment & $\begin{array}{c}\text { Neutralization activity } \\
\text { (reciprocal } \\
\text { plasma dilution) }\end{array}$ & $\begin{array}{c}\text { Antibody activity } \\
\left(\mathrm{OD}_{492} \text { value) }\right.\end{array}$ \\
\hline Control & 40 & 0.17 \\
Control & 40 & 0.15 \\
i.p.-challenged & 160 & 0.60 \\
i.p.-challenged & 80 & 0.60 \\
i.p.-challenged & 160 & 0.66 \\
i.p.-challenged & 160 & 0.82 \\
i.p.-challenged & 160 & 0.95 \\
i.p.-challenged & $80-160$ & 1.15 \\
\hline
\end{tabular}

point (Days 5 to 7) than in the head samples (Day 13) by conventional RT-PCR. Even the quantitative realtime RT-PCR, which is considered more sensitive than the conventional method, only detected a single weakly positive head sample (Day 5) prior to Day 13 post challenge. From Day 13, viral antigen was also detected by IHC in the retina and brain. However, the time for appearance of the virus in different organs may be dependent on the route of infection. The presence of virus in internal organs has also been shown in Atlantic halibut larvae challenged with virus by bath exposure (Grotmol et al. 1999). In their study, nodavirus was detected by IHC in the anterior intestine, spinal cord and brain on Day 18 and in the retina, liver and gills on Day 20 post challenge (water temperature of $6^{\circ} \mathrm{C}$ ). Thus, the piscine nodavirus may replicate in cells located in tissues other than in the central nervous system (CNS), though the nervous tissue is considered to be the main target tissue. There are 3 main ways for pathogens to enter CNS: local spread through adjoining tissue, neural spread, and viremia (Nathanson \& Tyler 1997). Immunohistochemical studies have revealed that nodavirus favors special areas of retina and brain in fish, and this could indicate that the virus enters CNS through paths along nerves or blood vessels (Nguyen et al. 1996, Grotmol et al. 1999, Húsgarð et al. 2001). In our study we only observed a limited number of nodavirus immunopositive cells in the tectum opticum of the brain and in the inner nuclear cell layer and ganglion cell layer of the retina. Also in sea bass Dicentrarchus labrax and turbot Scophthalmus maximus, survivors after experimental nodavirus infections showed immunopositive cells only in the inner cell layers of retina (Peducasse et al. 1999, Húsgarð et al. 2001). Nerve impulses from the retina progress from the rods and cones of the outer nuclear layer to the inner layers of retina and then through the nervus opticum to the tectum opticum of the brain. This close connection between the 3 virus-infected areas might indicate a retrograde axonal transport of nodavirus.

In the Atlantic halibut used in this study, immunopositive cells in the retina were detected adjacent to the circumferential germinal zone at the ciliary margin towards the iris. This location of immunopositive cells has also been described in the retina of turbot (Húsgarð et al. 2001). In Atlantic halibut with a persistent natural infection, clusters of nodavirus immunopositive cells were seen close to growth zones in the brain (Johansen et al. 2002). Their location close to the growth zones could indicate that nodavirus favors neural cells in early stages of proliferation. Teleosts have the ability to produce new neurons throughout their lifetime, but young fish have a higher proportion of neurons in early proliferation stage than older fish (Zupanc \& Horschke 1995).

In our study, the first detection of nodavirus by RTPCR was at Day 5 post challenge in fish that received virus by i.p.-injection. At the end of the experiment (Day 41), there was no sign of reduction of the amount of virus in the different organs in these fish. Whether the fish have the ability to get rid of the virus or whether the fish will become persistently infected for a limited period or for the whole of their life, is not known. In a recent study, a persistent infection of Atlantic halibut of approximately $5 \mathrm{~g}$ in a fish farm over a 4 mo period was demonstrated (Johansen et al. 2002). Thus, the infection may persist for a relatively long period within a fish population without them showing any signs of disease.

An ELISA method for the detection of anti-nodavirus antibodies was established. The novelty of the method relates to the improved binding efficiency of virus antigen, i.e. from lysate of infected SSN-1 cells in the coating process achieved by the use of additional salt $\left(\mathrm{NaCl}\right.$ or $\left.\left(\mathrm{NH}_{4}\right)_{2} \mathrm{SO}_{4}\right)$ in the coating buffer. Without the additional salt, virus antigen was bound inefficiently, resulting in consistently low OD values. The improved binding of specific antigen allows the use of a crude AHNNV preparation in a simple indirect ELISA procedure. The ELISA methods for detection of antinodavirus antibodies in fish reported so far have included either purified nodavirus antigen (Watanabe et al. 2000), sandwich techniques (Breuil \& Romestand 1999) or recombinant nodavirus protein (Huang et al. 2001, Húsgarð et al. 2001). Mushiake et al. (1992) employed a combination of partially purified fish IgM and purified nodavirus in a sandwich type ELISA. The optimized ELISA established in the present study will be useful for screening spawners for the elimination of nodavirus sero-positive fish in brood stock. 
It was demonstrated that only the i.p.-challenged fish showed a rise in the levels of plasma antinodavirus antibodies during the course of infection. The antibody levels were significantly different from control fish from Day 19 post-challenge. Húsgarð et al. (2001) showed that the humoral immune response of Atlantic halibut (mean weight 695 g) to i.p. immunization with recombinant nodavirus capsid protein in nonmineral oil came at a relatively late time point, with a marked increase between Weeks 12 and 16 postimmunization. In the turbot Scophthalmus maximus, these authors found that the immune response developed more gradually. Intraperitoneal immunization of sea bass (1 to $6 \mathrm{~kg}$ ) with heat-inactivated nodavirus in Freund's incomplete adjuvant resulted in a significant response after 6 wk (Breuil \& Romestand 1999). The use of live virus may explain the earlier response observed in the present study. The lack of antibody response in the bath-challenged group in the present study was paralleled by an absence of detectable nodavirus in these fish. The observed antibody response in the i.p.-challenged group was preceded by an early detection of nodavirus by RT-PCR in the kidney.

The teleost kidney has been established as an important secondary lymphoid organ in which immune responses are induced and conducted (Kaattari \& Irwin 1985). Antigen can be taken up and retained in macrophages and melanomacrophages in secondary lymphoid tissue (Lamers \& De Haas 1985, Herraez \& Zapata 1986) and these cell types are believed to be important as antigen processing and presenting cells (Vallejo et al. 1992). Húsgarð et al. (2001) observed that cells in the melanomacrophage centers of the kidney were IHC-positive for nodavirus in turbot surviving intramuscular challenge. These investigators speculated that virus was trapped and taken up in the form of immune complexes. As the present study did not obtain positive IHC results from the kidney, it was not possible to determine in which cell type(s) the nodavirus was found or whether the localization was confined to certain tissue compartments. However, the early detection of nodavirus by RT-PCR in the kidney, before an antibody response could be detected, makes it less likely that induced antibodies were participating in the localization of the virus. Our data do not elucidate whether the nodavirus infects cells in the kidney or whether the virus is trapped by or transported to the kidney by host mechanisms. This important question should be addressed in future studies of nodavirus infections.

The neutralizing activity against nodavirus in plasma from i.p.-challenged fish sampled on Day 41 was relatively low $(\sim 1: 160)$, but was higher than in samples from control fish. The neutralizing activity is probably mediated by specific antibodies, as little effect could be detected in plasma samples showing low OD values in the ELISA. In a recent report, Húsgarð et al. (2001) demonstrated substantial neutralizing activity in serum 20 wk after i.p.-immunization of Atlantic halibut with recombinant nodavirus capsid protein. In both the sevenband grouper Epinephelus septemfasciatus Thunberg (Tanaka et al. 2001) and the sea bass Dicentrarchus labrax (Skliris \& Richards 1999), neutralizing activity has been described. Thus, fish in general seem to generate neutralizing antibodies as a response to nodavirus infection. The extent and the time of appearance of this event may depend both on the antigen used and the environmental temperature. For further characterization of the antibody response of Atlantic halibut to nodavirus infection, the experimental period should be expanded.

In a separate study, fish from the farm that supplied the fish used in this study, were thoroughly investigated regarding the epicarditis observed in the present study (Johansen \& Poppe 2002). No infectious agent was found, and it is not known to which degree the epicarditis affects the general health of the fish. Other reports have shown that one infection may affect the outcome of an additional infection, and that this influence might be either positive or negative (LaPatra et al. 1995, Johansen \& Sommer 2001).

The control fish used in this study were not treated in the same way as the challenged fish, i.e. anaesthetized and injected or held under static conditions, and did therefore not constitute an ideal control group. The treatment of the challenged groups probably caused an amount of stress to the fish, and this in turn may have led to a degree of immune suppression not experienced by the control fish. Immune suppression may have facilitated the infection and also restrained the antibody response. Such restraint could have obscured the detection of a weak antibody response in the bath-challenged fish and also have reduced the detected antibody response of the i.p.challenged fish. The lack of treatment is not likely to have had any influence on the qualitative results obtained for the control fish, i.e. the data generated by IHC and RT-PCR methods.

This study is the first report describing experimentally induced infection with nodavirus in Atlantic halibut at a post-juvenile stage. Although, neither mortality nor clinical signs was observed following i.p.injection of the virus, this experimental infection model may be useful for further studies on pathogenesis, immune response and testing of vaccines in this species. Further experiments should include other methods of infections such as intramuscular injection and bath challenge using higher virus dose and a longer experimental period. 
Acknowledgements. This work was supported by The Research Council of Norway, Grant 124210-140. The authors thank Arne Guttvik at VESO Vikan AkvaVet for helpful assistance with the experiments. The skilled technical assistance of Karen Bækken Soleim, Randi Faller, Ingebjørg Modahl and Randi Terland is greatly acknowledged. Finally, the authors thank Dr. Charles McL. Press and Dr. Hilde Sindre for critical reviewing the manuscript.

\section{LITERATURE CITED}

Arimoto M, Mori K, Nakai T, Muroga K, Furusawa I (1993) Pathogenicity of the causative agent of viral nervous necrosis disease in striped jack, Pseudocaranx-dentex (Bloch and Schneider). J Fish Dis 16:461-469

Breuil G, Romestand B (1999) A rapid ELISA method for detecting specific antibody level against nodavirus in the serum of the sea bass, Dicentrachus labrax (L.): application to the screening of spawners in a sea bass hatchery. J Fish Dis 22:45-52

Breuil G, Pepin JF, Castric J, Fauvel C, Thiery R (2000) Detection of serum antibodies against nodavirus in wild and farmed adult sea bass: application to the screening of broodstock in sea bass hatcheries. Bull Eur Assoc Fish Pathol 20:95-100

Curtis PA, Drawbridge M, Iwamoto T, Nakai T, Hedrick RP, Gendron AP (2001) Nodavirus infection of juvenile white seabass, Atractoscion nobilis, cultured in southern California: first record of viral nervous necrosis (VNN) in North America. J Fish Dis 24:263-271

Dannevig BH, Nilsen R, Modahl I, Jankowska M, Taksdal T, Press CM (2000) Isolation in cell culture of nodavirus from farmed Atlantic halibut Hippoglossus hippoglossus in Norway. Dis Aquat Org 43:183-189

Frerichs GN, Rodger HD, Peric Z (1996) Cell culture isolation of piscine neuropathy nodavirus from juvenile sea bass, Dicentrarchus labrax. J Gen Virol 77:2067-2071

Fukuda Y, Nguyen HD, Furuhashi M, Nakai T (1996) Mass mortality of cultured sevenband grouper, Epinephelus septemfasciatus, associated with viral nervous necrosis. Fish Pathol 31:165-170

Grotmol S, Totland GK (2000) Surface disinfection of Atlantic halibut Hippoglossus hippoglossus eggs with ozonated sea-water inactivates nodavirus and increases survival of the larvae. Dis Aquat Org 39:89-96

Grotmol S, Totland GK, Kvellestad A, Fjell K, Olsen AB (1995) Mass mortality of larval and juvenile hatchery-reared halibut (Hippoglossus hippoglossus L.) associated with the presence of virus-like particles in vacuolated lesions in the central nervous system and retina. Bull Eur Assoc Fish Pathol 15:176-180

Grotmol S, Totland GK, Thorud K, Hjeltnes BK (1997) Vacuolating encephalopathy and retinopathy associated with a nodavirus-like agent: a probable cause of mass mortality of cultured larval and juvenile Atlantic halibut Hippoglossus hippoglossus. Dis Aquat Org 29:85-97

Grotmol S, Bergh O, Totland GK (1999) Transmission of viral encephalopathy and retinopathy (VER) to yolk-sac larvae of the Atlantic halibut Hippoglossus hippoglossus: occurrence of nodavirus in various organs and a possible route of infection. Dis Aquat Org 36:95-106

Grotmol S, Nerland AH, Biering E, Totland GK, Nishizawa T (2000) Characterization of the capsid protein gene from a nodavirus strain affecting the Atlantic halibut Hippoglossus hippoglossus and design of an optimal reverse-tran- scriptase polymerase chain reaction (RT-PCR) detection assay. Dis Aquat Org 39:79-88

Herraez MP, Zapata AG (1986) Structure and function of the melano-macrophage centres of the goldfish Carassius auratus. Vet Immunol Immunopathol 12:117-126

Huang B, Tan C, Chang SF, Munday B, Mathew JA, Ngoh GH, Kwang J (2001) Detection of nodavirus in barramundi, Lates calcarifer (Bloch), using recombinant coat protein-based ELISA and RT-PCR. J Fish Dis 24:135-141

Húsgarð S, Grotmol S, Hjeltnes BK, Rodseth OM, Biering E (2001) Immune response to a recombinant capsid protein of striped jack nervous necrosis virus (SJNNV) in turbot Scophthalmus maximus and Atlantic halibut Hippoglossus hippoglossus, and evaluation of a vaccine against SJNNV. Dis Aquat Org 45:33-44

Iwamoto T, Mori K, Arimoto M, Nakai T (1999) High permissivity of the fish cell line SSN-1 for piscine nodaviruses. Dis Aquat Org 39:37-47

Johansen LH, Sommer AI (2001) Infectious pancreatic necrosis virus infection in Atlantic salmon Salmo salar postsmolts affects the outcome of secondary infections with infectious salmon anaemia virus or Vibrio salmonicida. Dis Aquat Org 47:109-117

Johansen R, Poppe T (2002) Pericarditis and myocarditis in farmed Atlantic halibut Hippoglossus hippoglossus. Dis Aquat Org 49:77-81

Johansen R, Ranheim T, Hansen MK, Taksdal T, Totland GK (2002) Pathological changes in juvenile Atlantic halibut Hippoglossus hippoglossus persistently infected with nodavirus. Dis Aquat Org 50:161-169

Kaattari SL, Irwin MJ (1985) Salmonid spleen and anterior kidney harbor populations of lymphocytes with different B cell repertoires. Dev Comp Immunol 9:433-444

Kärber G (1931) Beitrag zur kollektiven Behandlung pharmakologischer Reienversuche. Arch Exp Pathol Pharmakol 162:480-483

Lamers CH, De Haas MJ (1985) Antigen localization in the lymphoid organs of carp (Cyprinus carpio). Cell Tissue Res 242:491-498

LaPatra SE, Lauda KA, Jones GR (1995) Aquareovirus interference mediated resistance to infectious hematopoietic necrosis virus. Vet Res 26:455-459

Lowry OH, Rosebrough NJ, Farr AL, Randall RJ (1951) Protein measurement with the folin phenol reagent. J Biol Chem 193:265-275

Mori KI, Nakai T, Muroga K, Arimoto M, Mushiake K, Furusawa I (1992) Properties of a new virus belonging to nodaviridae found in larval striped jack (Pseudocaranx dentex) with nervous necrosis. Virology 187:368-371

Munday BL, Nakai T (1997) Nodaviruses as pathogens in larval and juvenile marine finfish. World J Microbiol Biotechnol 13:375-381

Munday BL, Kwang J, Moody N (2002) Betanodavirus infections of teleost fish: a review. J Fish Dis 25:127-142

Mushiake K, Arimoto M, Furusawa T, Furukawa I, Nakai T, Muroga K (1992) Detection of antibodies against striped jack nervous necrosis virus (SJNNV) from brood stocks of striped jack. Nippon Suisan Gakkaishi 58:2351-2356

Mushiake K, Nishizawa T, Nakai T, Furusawa I, Muroga K (1994) Control of VNN in striped jack-selection of spawners based on the detection of SJNNV gene by polymerase chain-reaction (PCR). Fish Pathol 29:177-182

Nathanson N, Tyler KT (1997) Entry, dissemination, shedding and transmission of viruses. In: Nathanson N (ed) Viral pathogenesis. Lippincott-Raven Publishers, Philadelphia, p 13-33

Nguyen HD, Nakai T, Muroga K (1996) Progression of striped 
jack nervous necrosis virus (SJNNV) infection in naturally and experimentally infected striped jack Pseudocaranx dentex larvae. Dis Aquat Org 24:99-105

Peducasse S, Castric J, Thiéry R, Jeffroy J, LeVen A, Laurencin FB (1999) Comparative study of viral encephalopathy and retinopathy in juvenile sea bass Dicentrarchus labrax infected in different ways. Dis Aquat Org 36: $11-20$

Skliris GP, Richards RH (1999) Induction of nodavirus disease in seabass, Dicentrarchus labrax, using different infection models. Virus Res 63:85-93

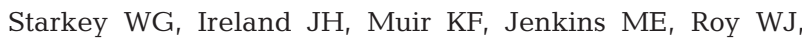
Richards RH, Ferguson HW (2001) Nodavirus infection in Atlantic cod and Dover sole in the UK. Vet Record 149: 179-181

Editorial responsibility: Jo-Ann Leong,

Kaneohe, Hawaii, USA
Tanaka S, Mori K, Arimoto M, Iwamoto T, Nakai T (2001) Protective immunity of sevenband grouper, Epinephelus septemfasciatus Thunberg, against experimental viral nervous necrosis. J Fish Dis 24:15-22

Vallejo AN, Miller NW, Clem LW (1992) Antigen processing and presentation in teleost immune responses. In: Faisal M, Hetrick FM (eds) Annual review of fish diseases 2. Pergamon Press, New York, p 73-89

Watanabe K, Nishizawa T, Yoshimizu M (2000) Selection of brood stock candidates of barfin flounder using an ELISA system with recombinant protein of barfin flounder nervous necrosis virus. Dis Aquat Org 41:219-223

Zupanc GKH, Horschke I (1995) Proliferation zones in the brain of adult gymnotiform fish - a quantitative mapping study. J Comp Neurol 353:213-233

Submitted: March 5, 2002; Accepted: September 26, 2002 Proofs received from author(s): February 7, 2003 